\title{
Evaluasi Fasilitas Sisi Udara Bandara Halim Perdanakusuma, Jakarta Timur
}

\author{
Dian Ayu Wicahyani dan Ervina Ahyudanari \\ Departemen Teknik Sipil, Institut Teknologi Sepuluh Nopember (ITS) \\ Corresponding Author: ervina@ce.its.ac.id
}

\begin{tabular}{|c|c|}
\hline ARTIKEL INFO & ABSTRAK \\
\hline $\begin{array}{l}\text { Kata Kunci } \\
\text { Bandara Halim Perdanakusuma, } \\
\text { Geometrik sisi udara, } \\
\text { Kapasitas runway, } \\
\text { Runway, Taxiway. }\end{array}$ & $\begin{array}{l}\text { Bandara Halim Perdanakusuma berfungsi sebagai bandara mliter, yang } \\
\text { mana di desain untuk kegiatan militer. Lokasi Bandara Halim } \\
\text { Perdanakusuma terletak di Jakarta Timur dengan elevasi } 26 \text { mdpl (=85,3 ft) } \\
\text { yang memiliki } 1 \text { buah landasan pacu (runway) dengan arah 06-24. Pada } \\
\text { tanggal } 10 \text { Januari } 2014 \text {, untuk mengurangi kepadatan penerbangan dari } \\
\text { Bandara Internasional Soekarno-Hatta, Bandara Halim Perdanakusuma } \\
\text { dibuka untuk beroperasi sementara menjadi bandara komersial hingga saat } \\
\text { ini. Dengan adanya penambahan fungsi bandara, hal yang perlu } \\
\text { diperhatikan adalah apakah desain Bandara Halim Perdanakusuma sudah } \\
\text { memenuhi ketentuan standard penerbangan sipil seperti yang diisyaratkan } \\
\text { pada ICAO Annex } 14 \text { serta FAA. Berdasarkan kondisi eksisting, Bandara } \\
\text { Halim Perdanakusuma memiliki panjang runway sebesar } 3000 \text { x } 45 \text { meter } \\
\text { dengan arah runway } 06 \text { - } 24 \text {. Lebar taxiway } \pm 25 \text { meter, memiliki } 2 \text { buah } \\
\text { exit taxiway dengan sudut } 90^{\circ} \text { dan } 1 \text { buah exit taxiway dengan sudut } 45^{\circ} \text {. } \\
\text { Untuk lamanya penggunaan runway/ROT maksimum sebesar } 36 \text { detik. } \\
\text { Dari evaluasi pada Studi ini didapatkan arah runway sama seperti eksisting, } \\
\text { yaitu } 06 \text { - } 24 \text {, tetapi utilisasi runwaynya menurun menjadi } 98,16 \% \text { karena } \\
\text { adanya komponen crosswind. Panjang runway setelah dievaluasi } \\
\text { didapatkan sebesar } 3180 \text { meter dengan lebar runway } 45 \text { meter. Lebar } \\
\text { taxiway sesuai dengan ICAO dan FAA sebesar } 15 \text { meter, memiliki } 2 \text { buah } \\
\text { exit taxiway dengan sudut } 90^{\circ} \text { dan } 1 \text { buah exit taxiway dengan sudut } 45^{\circ} \text {. } \\
\text { Adanya penambahan panjang runway pada Runway } 24 \text { sebesar } 180 \text { meter. } \\
\text { Kapasitas runway eksisting di lapangan sebesar } 17 \text { operasi/jam. Secara } \\
\text { matematis sebesar } 38 \text { operasi/jam, sedangkan yang disimulasikan dengan } \\
\text { time - space diagram sebesar } 35 \text { operasi/jam. Berarti lokasi exit taxiway } \\
\text { eksisting mampu menampung pergerakan pesawat eksisting. }\end{array}$ \\
\hline
\end{tabular}

\section{PENDAHULUAN}

Bandara Halim Perdanakusuma merupakan bandara militer yang terletak di Jakarta Timur dengan elevasi 26 mdpl (85,3 ft dpl). Berdasarkan kondisi eksisting saat ini, Bandara Halim Perdanakusuma memiliki 1 buah runway sepanjang 3000 meter $\times 45$ meter, 5 buah taxiway sepanjang 150 meter $\times 30$ meter, 2 buah apron (apron utara sepanjang 711 meter $\times 125$ meter, dan apron selatan sepanjang 470 meter $\times 135$ meter). Arah runway pada Bandara Halim Perdanakusuma R06 dan R24, menggunakan jenis perkerasan Aspal Hotmix dengan PCN 86 F/C/X/U. Saat ini Bandara Halim Perdanakusuma mampu dilalui pesawat dengan ukuran boeing-747.

Pada tanggal 10 Januari 2014, untuk mengalihkan penerbangan dari Bandara Internasional Soekarno-Hatta yang dinilai telah penuh sesak, Bandara Halim Perdanakusuma dibuka untuk beroperasi sementara menjadi bandara komersial hingga saat ini. Setelah berubah fungsi menjadi bandara komersial, Bandara Halim Perdanakusuma mengalami masalah, misalnya saja pada April 2014, terjadi kecelakaan pesawat antara Batik Air dan Transnusa, yang mana pada saat itu Transnusa dalam keadaan kosong yang sedang ditarik oleh towing dari apron utara menuju apron selatan, dan Batik Air take off dari runway yang juga dilalui pesawat Transnusa menuju apron selatan.

Adanya perubahan fungsi tersebut menjadi dasar pemikiran untuk mengevaluasi fasilitas sisi udara Bandara Halim Perdanakusuma. Hasil evaluasi ini akan digunakan untuk perencanaan ulang yang memperhatikan kebutuhan penerbangan sipil yang bertumbuh di Halim Perdanakusuma.

\section{A. Rumusan Masalah}

Berdasarkan latar belakang diatas, dapat dirumuskan beberapa masalah yang akan diselesaikan pada studi ini, yaitu:

1. Apakah arah runway sudah mencapai utilisasi sebesar 95\% sesuai dengan jenis pesawat eksisting?

2. Bagaimana kondisi eksisting fasilitas sisi udara Bandara Halim Perdanakusuma? Fasilitas yang dimaksud adalah geometrik sisi udara Bandara Halim Perdanakusuma terkait runway dan taxiway, penggunaan exit taxiway, ROT (Runway Occupancy 
Time), serta marka pada sisi udara Bandara Halim Perdanakusuma.

3. Bagaimana kondisi eksisting kapasitas runway pada Bandara Halim Perdanakusuma secara teoritis dan praktik?

\section{B. Tujuan}

Dengan rumusan masalah tersebut, maka tujuan yang diharapkan tercapai adalah sebagai berikut:

1. Mengetahui apakah arah runway sudah mencapai utilisasi sebesar 95\% sesuai dengan jenis pesawat eksisting.

2. Mengevaluasi kondisi eksisting fasilitas sisi udara Bandara Halim Perdanakusuma. Fasilitas yang dimaksud adalah geometrik sisi udara Bandara Halim Perdanakusuma terkait runway dan taxiway, penggunaan exit taxiway, ROT (Runway Occupancy Time), serta marka pada sisi udara Bandara Halim Perdanakusuma.

3. Mengetahui kondisi kapasitas runway eksisting pada Bandara Halim Perdanakusuma secara teoritis dan praktik

\section{Batasan Masalah}

Dalam penulisan ini dibatasi oleh masalah-masalah sebagai berikut:

1. Perencanaan ulang hanya dilakukan pada pesawat komersial yang mendarat/mengudara di Bandara Halim Perdanakusuma;

2. Tidak menganalisis apron;

3. Permukaan runway dalam kondisi kering;

4. Tidak menganalisis perkerasan.

\section{Lokasi Studi}

Studi ini dilakukan di Bandara Halim Perdanakusuma (kode IATA: HLP, kode ICAO: WIIH), berada di daerah ibukota, tepatnya di Jakarta Timur, 12,58 km dari ibukota provinsi dan ibukota negara. Gambar 1 merupakan lokasi Bandara Halim Perdanakusuma di Jakarta. Pada gambar tersebut, Bandara Halim Perdanakusuma berada di Kota Jakarta Timur, berjarak 29,90 km dari Bandara Internasional Soekarno - Hatta. Gambar 2 menunjukan layout Bandara Halim Perdanakusuma, yang terdiri dari 1 buah runway, 2 buah apron, 5 buah exit taxiway.

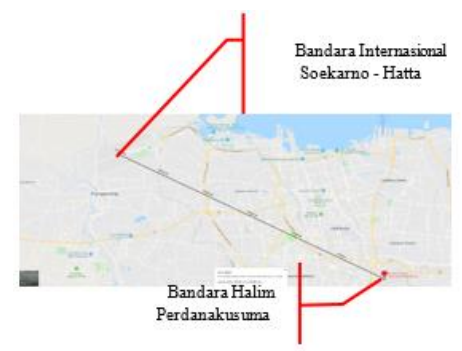

Gambar 1. Lokasi Bandara Halim Perdanakusuma, Jakarta Timur, Indonesia (Google Maps)

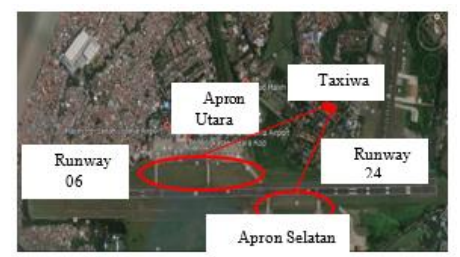

Gambar 2. Layout Bandara Halim Perdanakusuma, Jakarta Timur, Indonesia (Goggle Earth)

\section{METODOLOGI}

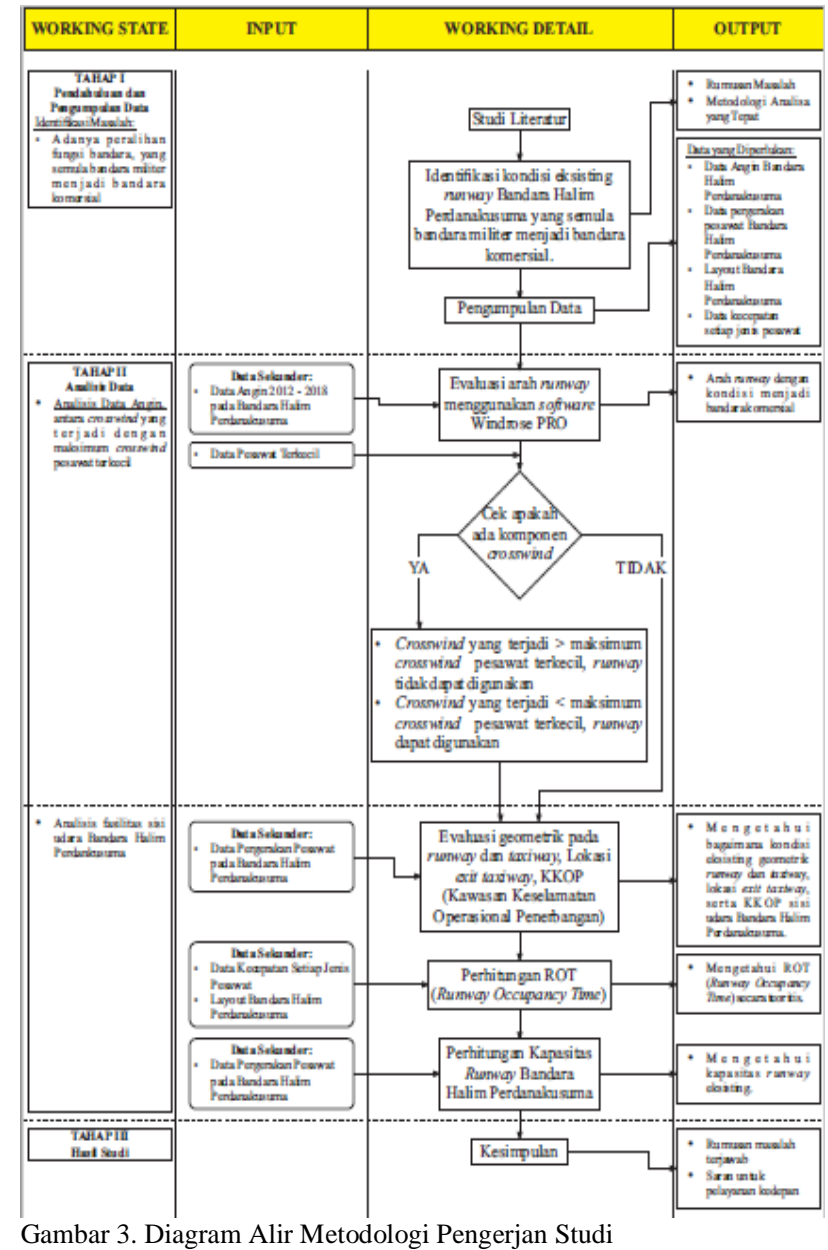

\section{HASIL ANALISA DAN PERENCANAAN}

\section{A. Analisa Data Angin}

Data angin diperoleh melalui website https://www7.ncdc.noaa.gov/CDO/dataproduct, dengan data dari bulan Januari 2013 hingga Desember 2018 (selama 7 tahun). Diketahui dari Chart Bandara Halim Perdanakusuma, arah runway eksisting adalah $60^{\circ}-240^{\circ}$ (06 - 24). Dari Analisa windrose didapatkan hasil seperti pada Gambar 4, arah runway eksisting sama dengan arah runway analisa, hanya saja terdapat penurunan utilisasi karena adanya komponen crosswind. Komponen crosswind dihitung untuk setiap proyeksi sudut $10^{\circ}$, dikoreksi hingga 1 lingkaran $\left(360^{\circ}\right)$.

Penurunan utilisasi runway sebesar $1,84 \%$ yang didapat dari jumlah data angin yang $>13$ knot dibagi jumlah data crosswind $>13$ knot. Sehingga usability factor runway pada Bandara Halim Perdanakusuma menjadi 98,16\%. Usability factor sudah memenuhi syarat minimal, yaitu $>95 \%$ [1][2], dan [3].

\section{B. Evaluasi Runway}

Berkaitan dengan dimensi geometrik pada runway sesuai dengan standard pada FAA [1], ICAO [2]. Didapat lebar runway sebesar 45 meter dengan panjang runway 3180 meter. RESA berukuran 240 meter dengan lebar 45 meter. Stopway terletak 60 meter sebelum ujung runway strips dengan lebar 45 meter. dimensi clearway dengan Panjang 150 meter dengan lebar 300 meter. 


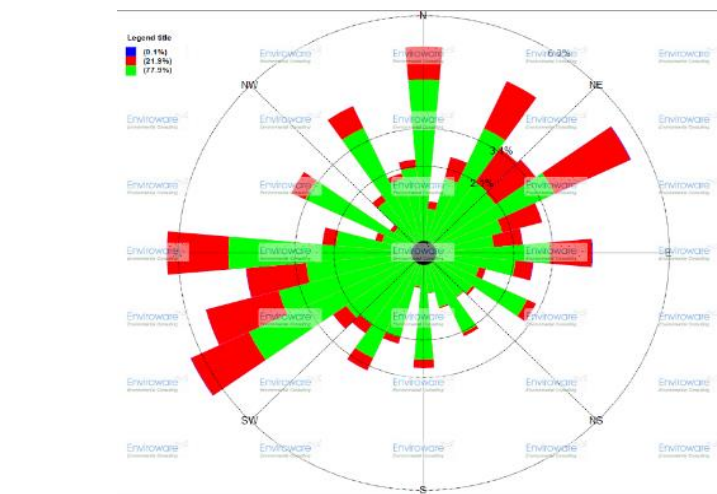

Gambar 4. Windrose Bandara Halim Perdanakusuma.

\section{Evaluasi Taxiway}

Berkaitan dengan dimensi geometrik pada runway sesuai dengan standard pada FAA [1], ICAO [4],. Didapat lebar taxiway sebesar 15 meter. Jarak antara taxiway dengan runway sejauh 168 meter.

\section{Penentuan Lokasi Exit Taxiway}

Dapat dilihat pada Gambar 2, jarak terpanjang antara threshold dengan lokasi exit taxiway sebesar 1981 meter (N1). Sedangkan untuk pesawat terbesar dengan landing distance [5] sebesar 2067 meter, Boeing 737 - 800, untuk dapat menggunakan exit taxiway N1 harus putar balik pada runway 06 agar dapat mengguakan exit taxiway N1. Untuk jarak yang lainnya dapat dilihat pada Tabel 1 .

\begin{tabular}{|c|c|c|c|c|} 
Tabel 1. Lokasi Exit Taxiway di Lapangan \\
\cline { 2 - 5 } \multicolumn{1}{c|}{$\begin{array}{c}\text { N1 } \\
(\mathrm{m})\end{array}$} & $\begin{array}{c}\mathrm{N} 2 \\
(\mathrm{~m})\end{array}$ & $\begin{array}{c}\text { N3 } \\
(\mathrm{m})\end{array}$ & \multicolumn{1}{c}{ Runway 24 } \\
\hline Runway 06 & 820 & 1224 & 1692 & \\
\hline & 1981 & 1574 & 1116 & R \\
\cline { 2 - 5 } & $90^{\circ}$ & $90^{\circ}$ & $45^{\circ}$ & \multicolumn{1}{c}{} \\
\cline { 2 - 4 } & &
\end{tabular}

Untuk mengetahui lokasi exit taxiway eksisting, dapat dihitung dengan menggunakan "Metode Tiga Segmen". Contoh perhitungan menggunakan pesawat terbesar, Boeing 737 - 800, dengan approach speed sebesar 142 knot, termasuk pesawat dalam kategori D. Sudut exit taxiway eksisting sebesar $90^{\circ}$, dengan kecepatan keluar sebesar 13 knots. Maka,

$\mathrm{S} 1=450$ meter (pesawat kategori D). Koreksi S1 sebesar $75 \%, S_{1}=\frac{450}{75 \%}=600$ meter.

$S_{2}=5 \times(142-10)=660$ meter

$S_{3}=\frac{(142-15)^{2}-13^{2}}{8(1,5)}=1330$ meter

Maka total landasan dari threshold menuju ke exit taxiway $=S_{1}+S_{2}+S_{3}=600+660+1330=$ 2590 meter.

Hasil perhitungan exit taxiway eksisting dapat dilihat pada Tabel 2.

Tabel 2. Lokasi Exit Taxiway Eksisting $\left(90^{\circ}\right)$

\begin{tabular}{|c|c|c|c|c|c|c|}
\hline \multirow{3}{*}{$\begin{array}{c}\text { Tipe } \\
\text { Pesawat }\end{array}$} & Kecepatan & \multirow{3}{*}{$\begin{array}{l}\text { Kategori } \\
\text { Pesawat }\end{array}$} & S1 & S2 & $\mathrm{S} 3$ & Total Per \\
\hline & Approach & & & & & E. Runway Occupancy Time (ROT) \\
\hline & knots & & $\mathrm{m}$ & $\mathrm{m}$ & $\mathrm{m}$ & $\mathrm{m}$ Mengelompokkan pesawat \\
\hline B733 & 130 & $\mathrm{C}$ & 600 & 600 & 1088 & 2288 Mengelompokkan \\
\hline A320 & 137 & $\mathrm{C}$ & 600 & 635 & 1226 & 2461 berdasarkan pada approach speed. Kemudian menen \\
\hline B738 & 142 & $\mathrm{D}$ & 600 & 660 & 1330 & 2590 komponen apa saja untuk menghitung runway оссирап \\
\hline AT76 & 113 & B & 333 & 515 & 786 & 1635 time (ROT), yang dapat dilihat pada Tabel 4 deng \\
\hline CRJX & 140 & $\mathrm{C}$ & 600 & 650 & 1288 & 2538 penjelasan sebagai berikut. \\
\hline AT75 & 113 & B & 333 & 515 & 786 & 1635 1. Menghitung waktu yang digun \\
\hline A20N & 137 & C & 600 & 635 & 1226 & 2461 menuju touchdown, dengan $\mathrm{p}$ \\
\hline
\end{tabular}

Dari Tabel 2, diketahui lokasi exit taxiway eksisting $\left(90^{\circ}\right)$, jarak terjauh sebesar 2590 meter, sedangkan di lapangan lokasi exit taxiway terjauh sebesar 1981 meter, berarti kondisi di lapangan masih kurang dari eksisting secara matematis dengan kecepatan keluar sebesar 13 knots. Kondisi eksisting di lapangan masih dapat digunakan, tetapi untuk pesawat B738 harus berjalan hingga ke runway 06 baru dapat keluar menggunakan exit taxiway terdekat (N1) sesuai dengan kecepatan yang direncanakan (13 knots).

Karena adanya penambahan panjang runway sebesar 180 meter pada Runway 24, maka lokasi exit taxiway menjadi lebih jauh. Lokasi exit taxiway dapat dilihat pada Tabel 1. Ilustrasi penambahan panjang runway rencana dapat dilihat pada Gambar 5 (diberi garis kuning).

Tabel 3

Lokasi exit taxiway adanya penambahan panjang runway

\begin{tabular}{|c|c|c|c|c|}
\cline { 2 - 4 } \multicolumn{1}{c|}{$\begin{array}{c}\text { N1 } \\
(\mathrm{m})\end{array}$} & $\begin{array}{c}\text { N2 } \\
(\mathrm{m})\end{array}$ & $\begin{array}{c}\text { N3 } \\
(\mathrm{m})\end{array}$ & \multicolumn{1}{c}{} \\
\hline Runway 06 & 820 & 1224 & 1692 & \\
\hline & 2161 & 1754 & 1296 & Runway 24 \\
\cline { 2 - 5 } & $90^{\circ}$ & $90^{\circ}$ & $45^{\circ}$ & \multicolumn{1}{c}{} \\
\cline { 2 - 5 }
\end{tabular}

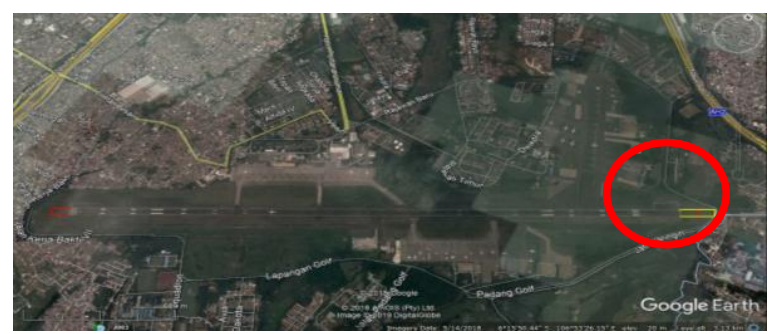

Gambar 5. Penambahan Panjang runway pada Runway 24.

Dari Tabel 3, lokasi exit taxiway N2 sudah sesuai dengan lokasi dari Gambar 5 dengan kecepatan exit rencana (13 knots), yang digunakan untuk pesawat AT76 dan AT75. Untuk exit taxiway N1 masih belum sesuai dengan keperluan exit taxiway dengan kecepatan keluar yang direncanakan (13 knots).

Pada Studi ini desain sisi udara Bandara Halim Perdanakusuma direncanakan diganti dengan taxiway menuju ke ujung threshold kedua runway, agar mempermudah pergerakan di runway. Dan rapid exit taxiway (N3) dengan sudut $45^{\circ}$, yang hanya digunakan untuk keluar menuju runway untuk melakukan takeoff pada Runway 24 dihapuskan, diganti dengan taxiway yang menuju ke threshold runway. Hasil desain sisi udara Bandara Halim Perdanakusuma dapat dilihat pada Gambar 6.

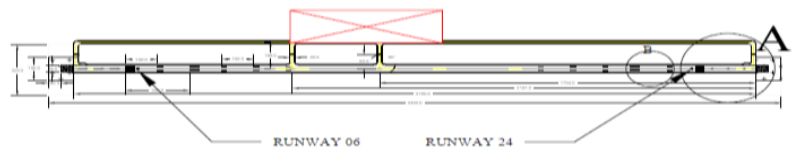

Gambar 6. Hasil Perencanaan Ulang Sisi Udara Bandara Halim 
$0,76 \mathrm{~m} / \mathrm{s}$. Kecepatan touchdown memiliki selisih 5 knots -8 knots dari kecepatan pendekat (approach speed);

2. Menambahkan 3 detik, sebagai waktu yang diperlukan roda depan untuk menyentuh perkerasan runway;

3. Menghitung waktu pengereman, dengan pelambatan di darat, $\mathrm{a}_{2}=1,52 \mathrm{~m} / \mathrm{s}$;

4. Waktu yang diperlukan untuk berbelok ke exit taxiway, $\mathrm{t}=10$ detik [6].

Rumus yang digunakan untuk menghitung lamanya waktu penggunaan runway dapat dihitung dengan rumus berikut.

$$
R O T=\frac{V_{o t}-V_{t d}}{2 a_{1}}+3+\frac{V_{t d}-V_{e x}}{2 a_{2}}+t
$$

Contoh perhitungan ROT menggunakan pesawat B738 dalam kondisi eksisting $\left(90^{\circ}\right)$, berikut perhitungannya. $\frac{V_{o t}-V_{t d}}{2 a_{1}}=\frac{73,05-68,93}{2 \times 0,76}=2,71 \mathrm{~s}$

$t=10 \mathrm{~s}$

$\frac{V_{t d}-V_{e x}}{2 a_{2}}=\frac{68,93-7,20}{2 \times 1,52}=20,31 s$

$R O T=\frac{V_{o t}-V_{t d}}{2 a_{1}}+3+\frac{V_{t d}-V_{e x}}{2 a_{2}}+t$

$R O T=2,71+3+20,31+10$

$R O T=36 s$

Tabel 4. Komponen untuk ROT

\begin{tabular}{ccccccc}
\hline \multirow{2}{*}{$\begin{array}{c}\text { Tipe } \\
\text { Pesawat }\end{array}$} & Vot & Vtd & $\begin{array}{c}\text { Vex } \\
90^{\circ}\end{array}$ & $\begin{array}{c}\text { Vex } \\
30^{\circ}\end{array}$ & a1 & a2 \\
\cline { 2 - 7 } & $\mathrm{m} / \mathrm{s}$ & $\mathrm{m} / \mathrm{s}$ & $\mathrm{m} / \mathrm{s}$ & $\mathrm{m} / \mathrm{s}$ & $\mathrm{m} / \mathrm{s} 2$ & $\mathrm{~m} / \mathrm{s} 2$ \\
\hline B733 & 68,42 & 64,30 & 7,20 & 26,75 & 0,76 & 1,52 \\
A320 & 69,96 & 65,84 & 7,20 & 26,75 & 0,76 & 1,52 \\
B738 & 73,05 & 68,93 & 7,20 & 26,75 & 0,76 & 1,52 \\
AT76 & 58,13 & 54,01 & 7,20 & 26,75 & 0,76 & 1,52 \\
CRJX & 72,02 & 67,90 & 7,20 & 26,75 & 0,76 & 1,52 \\
AT75 & 58,13 & 54,01 & 7,20 & 26,75 & 0,76 & 1,52 \\
A20N & 69,96 & 65,84 & 7,20 & 26,75 & 0,76 & 1,52 \\
\hline
\end{tabular}

Hasil perhitungan runway occupancy time (ROT) eksisting dengan sudut $90^{\circ}$, dapat dilihat pada Tabel 5 .

Tabel 5. Hasil Perhitungan ROT Eksisting

\begin{tabular}{cccccc}
\hline $\begin{array}{c}\text { Tipe } \\
\text { Pesawat }\end{array}$ & Kategori & (Vot-Vtd)/2a1 & (Vtd-Ve)/2a2 & t (s) & ROT (s) \\
\hline B733 & C & 2,71 & 18,78 & 10 & 34 \\
A320 & C & 2,71 & 19,29 & 10 & 35 \\
B738 & D & 2,71 & 20,31 & 10 & 36 \\
AT76 & B & 2,71 & 15,40 & 10 & 31 \\
CRJX & C & 2,71 & 19,97 & 10 & 36 \\
AT75 & B & 2,71 & 15,40 & 10 & 31 \\
A20N & C & 2,71 & 19,29 & 10 & 35 \\
\hline
\end{tabular}

F. Kapasitas Runway

Data yang diperlukan berupa:

1. Approach Speed (Kecepatan Pendekat)

Mengelompokkan pesawat berdasarkan kecepatan pendekat, berdasarkan Tabel 6. Besarnya kecepatan pendekat setiap jenis pesawat dapat dilihat pada Tabel 7 .

Tabel 6. Pengelompokkan pesawat berdasarkan kecepatan pendekat [5]

\begin{tabular}{ccc}
\hline Aircraft & \multicolumn{2}{c}{ Approach Speed } \\
\cline { 2 - 3 } Category & knots & $\mathrm{km} / \mathrm{h}$ \\
\hline A & 91 & 169 \\
B & $91-120$ & $169-222$ \\
C & $121-140$ & $224-259$ \\
D & $141-165$ & $261-306$ \\
\hline
\end{tabular}

Tabel 7. Kecepatan pendekat (approach speed) setiap jenis pesawat.

\begin{tabular}{cccc}
\hline \multirow{2}{*}{$\begin{array}{c}\text { Tipe } \\
\text { Pesawat }\end{array}$} & \multicolumn{2}{c}{$\begin{array}{c}\text { Kecepatan } \\
\text { Approach }\end{array}$} & \multirow{2}{*}{$\begin{array}{c}\text { Kategori } \\
\text { Pesawat }\end{array}$} \\
\cline { 2 - 3 } & knots & $\mathrm{km} / \mathrm{h}$ & \\
\hline B733 & 130 & 241 & $\mathrm{C}$ \\
A320 & 137 & 254 & $\mathrm{C}$ \\
B738 & 142 & 263 & $\mathrm{D}$ \\
AT76 & 113 & 209 & $\mathrm{~B}$ \\
CRJX & 140 & 259 & $\mathrm{C}$ \\
AT75 & 113 & 209 & $\mathrm{~B}$ \\
A20N & 137 & 254 & $\mathrm{C}$ \\
\hline
\end{tabular}

Pergerakan pesawat, digunakan data peak hour tanggal 21 Desember 2018, dapat dilihat pada Tabel 8.

Tabel 8. Pergerakan pesawat pada peak hour tanggal 21 Desember

\begin{tabular}{|c|c|c|c|}
\hline \multirow{18}{*}{ 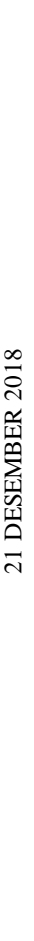 } & Waktu & Jenis Pesawat & Jenis Operasi \\
\hline & 2:35 PM & A320 (PK-LAZ) & Takeoff \\
\hline & 2:35 PM & $32 \mathrm{~A}()$ & Takeoff \\
\hline & $2: 45 \mathrm{PM}$ & A320 (PK-LUJ) & Takeoff \\
\hline & 2:45 PM & A320 (PK-GQJ) & Takeoff \\
\hline & 2:50 PM & A320 (PK-LAY) & Landing \\
\hline & 2:50 PM & A320 (PK-LAY) & Landing \\
\hline & 2:55 PM & A320 (PK-LAI) & Landing \\
\hline & 3:00 PM & 738() & Landing \\
\hline & 3:00 PM & B738 (PK-LBT) & Landing \\
\hline & 3:00 PM & A320 (PK-GQI) & Takeoff \\
\hline & 3:05 PM & $32 \mathrm{~A}()$ & Landing \\
\hline & 3:15 PM & A320 (PK-LUZ) & Landing \\
\hline & 3:20 PM & A320 (PK-LUL) & Landing \\
\hline & 3:20 PM & A20N (PK-GTI) & Landing \\
\hline & 3:30 PM & A320 (PK-LAP) & Landing \\
\hline & 3:30 PM & A320 (PK-GLS) & Landing \\
\hline & 3:30 PM & A320 (PK-LAY) & Takeoff \\
\hline
\end{tabular}

1. Dengan Metode Matematis (Matriks)

- Model kedatangan saja bebas kesalahan

Keadaan Merapat (Closing Case)

Diketahui $\delta_{i j}=4 n m i$ [7], $\mathrm{V}_{\mathrm{i}}(\mathrm{A} 320)=137$ knots, $\mathrm{V}_{\mathrm{j}}(\mathrm{B} 738)=142$ knots

$$
\begin{aligned}
& T_{i j}=\frac{\delta_{i j}}{V_{j}} \\
& =\frac{4}{142} \times 3600=101 \text { detik }
\end{aligned}
$$

Keadaan Merenggang (Opening Case)

Diketahui $\delta_{i j}=4 \mathrm{nmi}[10], \gamma=7,6 \mathrm{nmi}$ [7], $\mathrm{V}_{\mathrm{i}}$ $(\mathrm{B} 738)=142$ knots, $\mathrm{V}_{\mathrm{j}}(\mathrm{A} 320)=137$ knots

$$
\begin{aligned}
& T_{i j}=\frac{\delta_{i j}}{V_{i}}+\gamma\left(\frac{1}{V_{j}}-\frac{1}{V_{i}}\right) \\
& =\left(\frac{4}{142}+7,6\left(\frac{1}{137}-\frac{1}{142}\right)\right) \times 3600 \\
& =108 \text { detik }
\end{aligned}
$$

Apabila hasilnya ditabulasi kedalam matriks bebas kesalahan, $\left[\mathrm{M}_{\mathrm{ij}}\right]$, maka akan dihasilkan seperti pada Tabel 9.

Untuk prosentase kombinasi, $\left[\mathrm{P}_{\mathrm{ij}}\right]$, yang terjadi dalam operasi kedatangan, dapat dilihat pada matriks prosentase kedatangan pada Tabel 10. 
Tabel 9. Matriks bebas kesalahan [Mij]

\begin{tabular}{llcc} 
& & \multicolumn{2}{c}{ LEADING } \\
\cline { 2 - 3 } & & B738 & A320 \\
\hline \multirow{2}{*}{$\begin{array}{c}* \\
\text { Z }\end{array}$} & B738 & 101 & 101 \\
& A320 & 108 & 105 \\
\hline
\end{tabular}

Tabel 10. Matriks prosentase kedatangan [Pij]

\begin{tabular}{|c|c|c|c|}
\hline & \multicolumn{2}{|c|}{ LEADING } \\
\hline & & B738 & $\mathrm{A} 320$ \\
\hline $\bar{z} z$ & B738 & 0,10 & 0,10 \\
\hline$\cong=$ & A320 & 0,10 & 0,70 \\
\hline
\end{tabular}

Setelah mengetahui matriks bebas kesalahan, $\left[\mathrm{M}_{\mathrm{ij}}\right]$, dan matriks prosentase kombinasi, $\left[\mathrm{P}_{\mathrm{ij}}\right]$, selanjutnya menghitung nilai pada waktu layanan, $\mathrm{E}\left[\Delta \mathrm{T}_{\mathrm{ij}}\right]$.

$$
\begin{aligned}
& E\left[\Delta T_{i j}\right]=\sum\left[P_{i j}\right]\left[M_{i j}\right] \\
= & 0,10(101)+0,10(101)+0,10(108) \\
& +0,70(105) \\
= & 105 \text { detik } \\
& \text { Dengan demikian, kapasitas runway } \\
\text { melayani kedatangan saja sebesar: } & \\
C= & \frac{1}{E\left[\Delta T_{i j}\right]} \\
= & \frac{1}{105} \times 3600=35 \text { operasi } / \text { jam }
\end{aligned}
$$

Dengan demikian, kapasitas runway untuk

Model kedatangan saja kesalahan posisi

\section{Keadaan Merapat (Closing Case)}

$b_{i j}=\sigma_{0} \times q_{v}$

$$
=25 \text { detik }[6]
$$

\section{Keadaan Merenggang (Opening Case)}

Diketahui $B_{i j}=25$ detik [6], $\delta_{i j}=4 \mathrm{nmi}$ [1], $\mathrm{V}_{\mathrm{i}}(\mathrm{B} 738)=142$ knots, $\mathrm{V}_{\mathrm{j}}(\mathrm{A} 320)=137$ knots, didapat:

$$
\begin{aligned}
& B_{i j}=b_{i j}+\delta_{i j}\left(\frac{1}{V_{j}}-\frac{1}{V_{i}}\right) \\
& =\left(25+4\left(\frac{1}{137}-\frac{1}{142}\right)\right) \times 3600 \\
& =21 \text { detik }
\end{aligned}
$$

\begin{tabular}{|c|c|c|c|}
\hline & abel 12 & \multicolumn{2}{|c|}{ LEADING } \\
\hline & & B738 & A320 \\
\hline$F \boxminus$ & B738 & 126 & 126 \\
\hline$\nwarrow$ & A320 & 130 & 130 \\
\hline
\end{tabular}

Apabila hasil dari buffer time ditabulasi kedalam matriks, [ $\left.\mathrm{B}_{\mathrm{ij}}\right]$, maka akan dihasilkan seperti pada Tabel 11.

Tabel 11

Matriks buffer time [Bij]

\begin{tabular}{cccc} 
& & \multicolumn{2}{c}{ LEADING } \\
\cline { 3 - 4 } & & B738 & A320 \\
\hline \multirow{2}{*}{ B } & B738 & 25 & 25 \\
\cline { 3 - 4 } & A320 & 21 & 25 \\
\hline
\end{tabular}

Dengan menggabungkan matriks bebas kesalahan, $\left[\mathrm{M}_{\mathrm{ij}}\right]$, dan matriks buffer time, $\left[\mathrm{B}_{\mathrm{ij}}\right]$, menghasilkan jarak waktu antar kedatangan sebenarnya di ambang runway, maka didapat matriks $\left[\mathrm{M}_{\mathrm{ij}}\right]+\left[\mathrm{B}_{\mathrm{ij}}\right]$ seperti pada Tabel 12 .

Untuk prosentase kombinasi, $\left[\mathrm{P}_{\mathrm{ij}}\right]$, yang terjadi dalam operasi kedatangan, dapat dilihat pada matriks prosentase Tabel 10. Selanjutnya menghitung nilai pada waktu layanan, $\mathrm{E}\left[\Delta \mathrm{T}_{\mathrm{ij}}\right]$.

$$
E\left[\Delta T_{i j}\right]=\sum\left[P_{i j}\right]\left(\left[M_{i j}\right]+\left[B_{i j}\right]\right)
$$

$$
\begin{gathered}
=0,10(126)+0,10(126)+0,10(130) \\
\quad+0,70(130) \\
=123 \text { detik }
\end{gathered}
$$

\begin{tabular}{|c|c|c|c|}
\hline & \multicolumn{2}{|c|}{ LEADING } \\
\hline & & B738 & A320 \\
\hline$F \equiv$ & B738 & 0,00 & 0,00 \\
\hline & A 320 & 0,00 & 1,00 \\
\hline
\end{tabular}

Dengan demikian, kapasitas runway untuk melayani kedatangan saja sesuai dengan persamaan (5), sebesar:

$$
C=\frac{1}{E\left[\Delta T_{i j}\right]}=\frac{1}{123} \times 3600=30 \text { operasi } / \text { jam }
$$

- Model keberangkatan saja

Diketahui dari PANS - ATM, besarnya jarak pisah antarkeberangkatan - keberangkatan sebesar 60 detik (1 menit), jika pesawat yang mengikuti memiliki kecepatan lebih besar daripada pesawar yang didepannya jarak pisah sebesar 120 detik (2 menit).

\begin{tabular}{cccc} 
& & \multicolumn{2}{c}{ LEADING } \\
\cline { 3 - 4 } & & B738 & A320 \\
\hline \multirow{2}{*}{\begin{tabular}{c} 
Tabel 13. Jarak pisah minimum antar keberangkatan $\left[\mathrm{t}_{\mathrm{d}}\right]$ \\
\cline { 2 - 3 }
\end{tabular}} & $\mathrm{B} 738$ & 60 & 60 \\
& $\mathrm{~A} 320$ & 120 & 60 \\
\hline
\end{tabular}

Untuk prosentase kombinasi, $\left[\mathrm{P}_{\mathrm{ij}}\right]$, yang terjadi dalam operasi keberangkatan, dapat dilihat pada matriks prosentase keberangkatan pada Tabel 14.

Setelah mengetahui jarak pisah minimum antar keberangkatan, $\left[\mathrm{t}_{\mathrm{d}}\right]$, dan matriks prosentase keberangkatan, $\left[\mathrm{P}_{\mathrm{ij}}\right]$, selanjutnya menghitung nilai pada waktu layanan, $\mathrm{E}\left[\mathrm{t}_{\mathrm{d}}\right]$.

$$
\begin{aligned}
& E\left[t_{d}\right]=\sum\left[P_{i j}\right]\left[t_{d}\right] \\
& =0,00(60)+0,00(60)+0,00(120) \\
& =60 \text { detik } \quad+1,00(60)
\end{aligned}
$$

Dengan demikian, kapasitas runway untuk melayani keberangkatan saja sebesar:

$$
\begin{aligned}
& C=\frac{1}{E\left[t_{d}\right]} \\
& =\frac{1}{60} \times 3600=60 \text { operasi } / \text { jam }
\end{aligned}
$$

- Model operasi campuran

Tabel 15. Karakteristik Pengoperasian

\begin{tabular}{lcccc}
\hline A/C & $\begin{array}{c}\text { Approach } \\
\text { Speed } \\
\text { (knot) }\end{array}$ & \multirow{2}{*}{$\begin{array}{l}\text { ROT } \\
(\mathrm{s})\end{array}$} & \multicolumn{2}{c}{ Probabilitas Mix } \\
\hline B738 & 142 & 43 & 0,12 & Departure \\
A320 & 137 & 38 & 0,88 & 0,00 \\
\hline
\end{tabular}

Waktu pemakaian runway rata - rata $\mathrm{E}\left[\mathrm{R}_{\mathrm{i}}\right]$, merupakan jumlah dari perkalian probabilitas pesawat campuran pada jam sibuk dengan pemakain runway tiap pesawat.

$$
E\left[R_{i}\right]=0,12(38)+0,88(37)=39 \text { detik }
$$

Waktu pesawat yang datang untuk menempuh jarak 2 nm terakhir ke ambang runway (Horonjeff, 2010).

$$
\begin{gathered}
E\left[\frac{\delta_{d}}{V_{j}}\right]=\left[0,12\left(\frac{2}{140}\right)+0,88\left(\frac{2}{137}\right)\right] \times 3600 \\
=52 \text { detik }
\end{gathered}
$$

Buffer time yang diperlukan saat pesawat terjadi kesalahan posisi. 


$$
E\left[B_{i j}\right]=25 \text { detik }
$$

Waktu pelayanan antar keberangkatan di ambang runway.

$$
E\left[t_{d}\right]=60 \text { detik }
$$

Oleh karena itu, waktu antar kedatangan untuk dapat diselingi oleh keberangkatan, sebagai berikut.

$$
\begin{aligned}
E\left[\Delta T_{i j}\right] \geq & E\left[R_{i}\right]+E\left[\frac{\delta_{d}}{V_{j}}\right]+E\left[B_{i j}\right] \\
& +E\left[t_{d}\right]\left(n_{d}-1\right) \\
\geq & 38+52+25+60\left(n_{d}-1\right) \\
\geq & 116+60\left(n_{d}-1\right)
\end{aligned}
$$

Waktu kedatangan sebenarnya (pada saat kesalahan posisi) adalah 123 detik. Jika dilakukan satu keberangkatan diantara dua kedatangan, nilainya 116 detik. Jika dilakukan dua keberangkatan diantara dua kedatangan, nilainya 176 detik. Maka dari itu, hanya dapat dilakukan satu keberangkatan diantara dua kedatangan $\left(\mathrm{n}_{\mathrm{d}}\right.$ $=1)$, dan probabilitas kedatangan yang diselingi 1 keberangkatan adalah $\left(\mathrm{P}_{\mathrm{nd}}=0,15\right)$. Kapasitas runway pada kondisi eksisting untuk operasi campuran, sebagai berikut.

$$
\begin{aligned}
C=\frac{3600}{E\left[\Delta T_{i j}\right]}\left(1+n_{d} P_{n d}\right) & =\frac{3600}{116}(1+1(0,15)) \\
& =38^{\text {operasi }} / \text { jam }
\end{aligned}
$$

2. Dengan Metode Grafis (Time - Space Diagram)

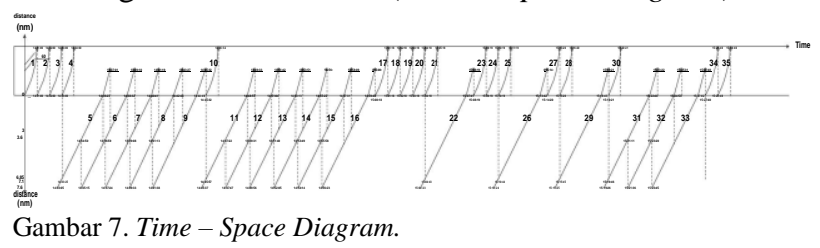

\section{G. Kawasan Keamanan Operasi Penerbangan (KKOP)}

Berdasarkan KKOP pada Gambar 7, untuk lateral surface (transitional surface, inner horizontal surface, conical surface, outer horizontal surface) banyak tedapat gedung - gedung tinggi, misalnya saja Menara Saidah dengan ketinggian 94 meter. Sedangkan untuk approach/landing surface terdapat Menara 165, Gedung Trakindo. Lokasi Menara Saidah, Menara 165, Gedung Trakindo dapat dilihat pada Gambar 8.

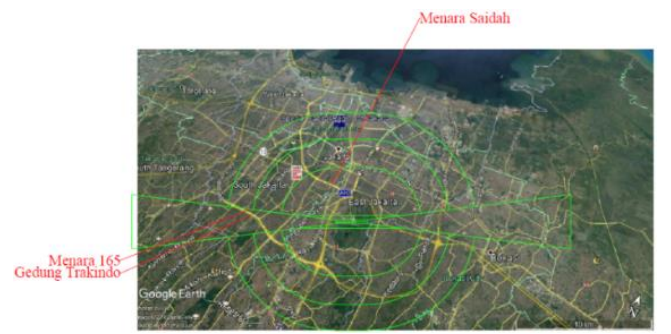

Gambar 8. Kawasan Keselamatan Operasi Penerbangan (KKOP) Bandara Halim Perdanakusuma, Jakarta Timur

\section{KESIMPULAN DAN SARAN}

\section{A. Kesimpulan}

Berdasarkan hasil perencanaan ulang geometri runway dan taxiway Bandara Halim Perdanakusuma, dapat diambil beberapa kesimpulan sebagai berikut:

1) Arah runway analisis masih sama dengan orientasi runway eksisting, yaitu 06 - 24 dengan usability factor sebesar $98,16 \%$
2) Perencanaan ulang pada fasilitas sisi udara Bandara Halim Perdanakusuma, meliputi:

a. Panjang runway eksisting sebesar 3000 meter, setelah dievaluasi menjadi sebesar 3180 meter, lebih panjang 180 meter dari runway eksisting. Kondisi eksisting hanya dapat melayani pesawat saat beban takeoff maksimum dengan ARFL sebesar 2612 meter. Lebar runway setelah di evaluasi sebesar 45 meter, masih sama dengan lebar runway eksisting.

b. Lebar taxiway setelah di evaluasi didapat sebesar 15 meter, sedangkan lebar taxiway eksisting sebesar \pm 25 meter, artinya lebar taxiway eksisting aman untuk digunakan karena melebihi dari standard ICAO dan FAA.

c. Lokasi exit taxiway yang telah ditambahkan dengan panjang runway, 180 meter, untuk N2 sudah memenuhi untuk lokasi exit taxiway dengan kecepatan yang direncanakan untuk sudut $90^{\circ}$ (14 knots). Sedangkan untuk N3, belum memenuhi dengan kecepatan rencana, sehingga pesawat harus berjalan hingga ke runway 06 untuk putar balik, kemudian dapat menggunakan exit taxiway terdekat dengan kecepatan yang direncanakan.

3) Kapasitas runway dilapangan saat peak hour (jam sibuk) sebesar 17 operasi/jam. Apabila dihitung secara teoritis, dapat menampung hingga 38 operasi/jam. Saat di simulasikan menggunakan time - space diagram, secara praktek dapat menampung hingga 35 operasi/jam. Artinya, kapasitas runway eksisting atau lokasi exit taxiway eksisting masih dapat menampung pergerakan pesawat yang ada.

\section{B. Saran}

Saran dalam perencanaan ulang geometri runway dan taxiway Bandara Halim Perdanakusuma, adalah sebagai berikut:

a) Perlunya koordinasi dalam melakukan takeoff ataupun landing untuk menghindari terjadinya crosswind, terutama untuk pesawat yang kecil. Crosswind sering terjadi mulai dari pukul 05.00 hingga pukul 10.00;

b) Sebaiknya dilakukan penambahan panjang runway agar dapat digunakan pesawat dengan beban maksimum (MTOW);

\section{DAFTAR PUSTAKA}

[1] Federal Aviation Administration, "Airport Design AC No. 150/5300-13," USA, 1989.

[2] ICAO, Aerodrome Design Manual, Part 1 Runways. 2006

[3] ICAO (International Civil Aviation Organization), "Annex 14: Aerodromes Design and Operation Volume I (7th ed.)," Canada, 2016.

[4] ICAO, Aerodrome Design Manual, Part 2 Taxiways, Aprons and Holding Bays, 4th ed. 2005.

[5] D. A. Wicahyani, "Perencanaan Ulang Fasilitas Sisi Udara Bandara Halim Perdanakusuma, Jakarta Timur," Surabaya, 2019.

[6] R. Horonjeff and F. X. McKelvey, Planning and Design of Airport, 5th ed. New York: Mc Graw Hill, 2010.

[7] ICAO, Procedures for Air Navigation Services, Air Traffic Management, 14th ed. 2001. 